\title{
PENGARUH FRAMING EFFECT TERHADAP \\ PENGAMBILAN KEPUTUSAN INVESTASI DENGAN LOCUS OF CONTROL SEBAGAI VARIABEL PEMODERASI
}

\author{
Erlinda Kusuma Wardani \\ Alumni Prodi Akuntansi Universitas negeri Yogyakarta \\ erlinda.wardani@ymail.com \\ Sukirno \\ Jurusan Pendidikan Akuntansi Universtas Negeri Yogyakarta
}

\begin{abstract}
Abstrak: Pengaruh Framing Effect terhadap Pengambilan Keputusan Investasi dengan Locus of Control sebagai Variabel Pemoderasi. Penelitian ini bertujuan untuk mengetahui: (1) Pengaruh Framing Effect terhadap Pengambilan Keputusan Investasi (2) Pengaruh Framing Effect terhadap Pengambilan Keputusan Investasi dengan Locus of Control sebagai Variabel Pemoderasi. Penelitian ini adalah penelitian eksperimen dengan partisipan mahasiswa Jurusan Pendidikan Akuntansi Prodi Pendidikan Akuntansi 2010 dan Prodi Akuntansi 2011 yang berperan sebagai manajer keuangan. Penelitian eksperimen ini melibatkan 45 mahasiswa sebagai sampel yang telah memenuhi kriteria dan lulus uji manipulation check. Sebelum dilakukan eksperimen terlebih dahulu instrumen penelitian diuji coba pada pilot test yang melibatkan 30 mahasiswa Prodi Akuntansi kelas B 2010 yang tidak dilibatkan kembali pada eksperimen. Pada instrumen penelitian ini dilakukan uji validitas dan uji reliabilitas. Uji prasyarat analisis adalah uji normalitas dan uji homogenitas. Metode analisis data yang digunakan dalam menguji hipotesis adalah Univariate ANOVA. Hasil pengujian hipotesis 1 menunjukkan tingkat signifikansi sebesar 0,310. Pengambil keputusan yang berada pada kondisi Positive Framing akan melakukan investasi karena tidak terpengaruh oleh risiko yang akan ditanggung. Pada hasil pengujian hipotesis 2 nilai signifikansi sebesar 0,650 $(>0,05)$. Pengambil keputusan pada kondisi Negative Framing akan melakukan investasi, keputusan yang sama juga dilakukan oleh pengambil keputusan pada kondisi tanpa framing. Hasil pengujian hipotesis 3 dan 4 , nilai signifikan sebesar 0,787 . Hal ini mengindikasikan bahwa tidak terdapat pengaruh Locus of Control pada pengambilan keputusan investasi karena pengambil keputusan dengan internal locus of control atau pun external locus of control mengambil keputusan yang sama yaitu melakukan investasi.
\end{abstract}

Kata kunci: Framing Effect, Pengambilan Keputusan Investasi, Locus of Control.

Abstract: The Influence of Framing Effect on Investment Decision Making with Locus of Control as Moderating Variable. This study aims to determine: (1) the influence of Framing Effects on Investment Decision Making (2) the influence of Framing Effect on Investment Decision Making with Locus of Control as a moderating variable. This study is an experiment research with students of Accounting Education of Accounting Educational Department 2010 and 2011 as participants, which act as financial managers. This experimental study involves 45 students as the sample who have met the criteria and passed the manipulation check test. Before the experiment is conducted, the research instrument was tested using a pilot test involving 30 students of Accounting Education Class B academic year of 2010, who are not involved in the experiment again. This research experiment is tested by validity and reliability test. Requirements analysis test is a test of normality and homogeneity tests. Data analysis method used to test the hypothesis was Univariate ANOVA. The result of hypotheses testing 1 shows the significance value of 0.310. Decision makers who are in conditions of Positive Framing will make an investment because it is not affected by the risks possibly followed. Meanwhile the significance value of the hypothesis testing 2 was 0.650 (>0.05). Decision makers on the condition of Negative Framing will make an investment, the same decision are made by 


\section{JURNAL NOMINAL / VOLUME III NOMOR 1 / TAHUN 2014}

decision makers on the condition without framing too. The significant value of hypothesis testing 3 and 4 are the same that is 0.787. This indicates that there is no influence of Locus of Control on investment decision making because the decision makers with an internal locus of control or external locus make the same decision, which is making an investment.

Keywords: Framing Effect, Investment Decision Making, Locus of Control.

\section{PENDAHULUAN}

Pembuatan

keputusan

akan

menghasilkan keberhasilan atau kegagalan. Pengambilan selalu menjadi hal yang rumit, kompleks, dan krusial pada setiap organisasi. Dalam organisasi, pengambilan keputusan biasanya didefinisikan sebagai proses memilih diantara berbagai alternatif tindakan yang berdampak pada masa depan Arfan dan Muhammad (2005:203). Oleh karena itu, fungsi manajer dalam hal pengambilan keputusan adalah fungsi paling mendasar yang harus dapat dikuasai oleh manajer.

Seringkali seorang pembuat keputusan mengambil keputusan yang tidak tepat karena proses yang tidak memadai (Hammond, Keeney, dan Raiffa, 1998). Menurut Mintzberg dalam Usmara (2004 : 95), keputusan yang tepat dalam proses pengambilan keputusan hanya akan dapat diperoleh jika manajer mendapatkan informasi yang lengkap untuk menjadi pertimbangan. Setiap informasi yang dibutuhkan oleh manajer sebagai dasar pengambilan keputusan telah dikumpulkan oleh bawahan. Semua informasi dan data yang dikumpulkan bawahan tergabung dalam management information system (MIS).

Setiap bukti kecil menunjukkan bahwa manajer mengidentifikasi keputusan situasi dan membangun model hanya menggunakan keterangan dengan menarik data tertentu (Mintzberg dalam Usmara, 2004:97). Sikap manajer yang hanya menarik data tertentu sebagai pertimbangan dalam pengambilan keputusan, maka kemungkinan akan terbentuk framing dalam sebagian informasi yang diterima. Pembingkaian (framing) adalah suatu cara menggunakan bahasa untuk mengelola makna. Ini merupakan cara pemimpin untuk mempengaruhi bagaimana suatu kejadian harus dilihat atau dipahami. Pembingkaian melibatkan pemilihan dan penekanan satu atau lebih aspek dari suatu subjek dengan mengabaikan yang lain. (Robbins dan Judge,1998:80).

Menurut Arfan dan Muhammad (2005:204), tahap yang paling penting dalam proses pengambilan keputusan adalah memilih satu dari beberapa alternatif, tetapi keputusan akhir sering kali didasarkan pada pertimbangan politik dan psikologis dibandingkan pada fakta-fakta ekonomi. Jadi, faktor psikologis juga akan 


\section{JURNAL NOMINAL / VOLUME III NOMOR 1 / TAHUN 2014}

mempengaruhi pengambilan keputusan akhir. Untuk itu, perlu diketahui tingkat locus of control yang dimiliki pengambil keputusan untuk dapat memperkirakan bagaimana mereka akan mengambil keputusan. Lau (1988 : 52) dalam Rahmanto Aji (2009), mengartikan locus of control sebagai kontrol diri yang berkaitan dengan hal-hal yang menyangkut masalah perilaku dari individu yang bersangkutan.

\section{METODE PENELITIAN}

\section{Jenis Penelitian}

Desain penelitian ini adalah factorial experimental design. Desain faktorial merupakan modifikasi dari design true experimental, yaitu dengan memperhatikan kemungkinan adanya variabel moderator yang mempengaruhi perlakuan (variabel independen) terhadap hasil (variabel dependen) (Sugiyono, 2001: 67).Eksperimen ini menggunakan betweensubjects design dengan faktorial 2 x 2 untuk mengetahui respon yang berbeda dalam hal ini keputusan investasi pada setiap individu dengan pemberian treatment yang berbeda. Penelitian dilakukan di Fakultas Ekonomi Universitas Negeri Yogyakarta pada bulan Desember 2013.

\section{Prosedur}

Eksperimen dirancang dalam tahapan yang harus dikerjakan partisipan. Terdapat 4 tahapan sebagai berikut:
1) Tahap Pengisian Data Partisipan

Pada tahap ini, partisipan mengisikan data diri berupa nama, semester yang sedang ditempuh, IPK, dan jenis kelamin.

2) Tahap Treatment

Pada tahap ini, partisipan diberikan kasus dengan tiga jenis yang berbeda yaitu kasus dengan positive framing, negative framing, dan tanpa pembingkaian. Kasus tersebut memanipulasi partisipan sebagai manajer keuangan sebuah perusahaan Sriwijaya Air sebagai perusahaan yang berinvestasi pada penerbangan baru. Partisipan sebagai manajer keuangan mengambil keputusan untuk berinvestasi atau tidak pada jalur penerbangan baru. Pada tahap ini pula, partisipan diberikan kuesioner untuk mengukur Locus of Control setiap partisipan berdasarkan instrumen Spector dengan menggunakan 16 item pertanyaan. Tahap ini menentukan tingkat Locus of Control partisipan sehingga didapatkan partisipan yang memiliki Locus of Control tinggi (Internal Locus of Control), dan partisipan yang memiliki tingkat Locus of Control yang rendah (External Locus of Control).

3) Tahap Pengambilan Keputusan

Pada tahap ini, Peneliti meminta partisipan untuk memilih diantara dua opsi untuk menambah investasi atau tidak menambah investasi pada jalur penerbangan baru. Partisipan juga diminta menentukan tingkat keyakinan atas opsi yang mereka 


\section{JURNAL NOMINAL / VOLUME III NOMOR 1 / TAHUN 2014}

pilih. Tingkat keyakinan ini ditulis dengan memberikan tanda pada arbitrary scale dari pilihan sangat tidak yakin dan sangat yakin.

4) Tahap Manipulation Check

Manipulation check terdiri atas tiga soal. Partisipan diminta untuk menjawab benar atau salah pernyataan yang diberikan dalam soal-soal tersebut. Soal manipulation check ini merupakan kontrol atas jawaban yang diberikan oleh partisipan yang menunjukkan seberapa jauh tingkat pemahaman partispan atas kasus atau perlakuan yang diberikan.

Tabel 1. Desain Eksperimen 2 x 2

\begin{tabular}{|c|c|c|c|}
\hline \multirow{2}{*}{\multicolumn{2}{|c|}{ Treatment }} & \multicolumn{2}{|c|}{$L O C$} \\
\hline & & Internal & External \\
\hline \multirow{2}{*}{ 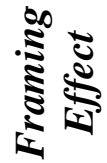 } & Positive & 1 & 3 \\
\hline & Negative & 2 & 4 \\
\hline
\end{tabular}

\section{Data dan Teknik Pengumpulan}

Data pada penelitian ini adalah data primer yang diperoleh melalui penelitian eksperimen. Instrumen penelitian yang digunakan adalah instrumen yang digunakan oleh Frasto Biyanto (2001) dan telah disesuaikan kembali oleh peneliti. Dalam penelitian Frasto Biyanto (2001) menggunakan instrumen dari Rutledge dan Hareel (1994). Dalam Instrumen Pengukuran Locus of Control mengadopsi instrumen Spector (1988) yang terdiri dari 16 nomor, dan menggunakan skala likert 5 poin.

\section{Teknik Analisis Data}

Teknik analisis data yang digunakan untuk menguji hipotesis-hipotesis penelitian, adalah Univariate Analysis of Variance (ANOVA).

\section{HASIL PENELITIAN DAN PEMBAHASAN}

Pada penelitian ini hipotesis-hipotesis diuji menggunakan Univariate ANOVA. Hasil uji dapat diketahui melalui tabel-tabel dibawah ini.

Tabel 2. Hasil Uji Hipotesis

\begin{tabular}{cccc}
\hline & Hip 1 & Hip 2 & Hip \\
& \& 4 \\
\hline Df & 1 & 1 & 2 \\
Mean & 2,700 & 0,300 & 0,501 \\
Square & & \\
F & 1,070 & 0,211 & 0,241 \\
Nilai & 0,310 & 0,650 & 0,787 \\
Signifikansi & & & \\
\hline
\end{tabular}

Hasil uji hipotesis menghasilkan nilai signifikansi sebesar $0,310(>0,05)$ yang berarti bahwa hipotesis ditolak atau tidak terdukung. Hal ini berarti bahwa hipotesis pertama yang menyatakan manajer pada kondisi positive framing akan lebih cenderung tidak melakukan investasi daripada manajer pada kondisi tanpa framing tidak terbukti.

Pada penelitian ini menunjukkan bahwa pembingkaian informasi tidak memberikan pengaruh terhadap pengambilan keputusan 


\section{JURNAL NOMINAL / VOLUME III NOMOR 1 / TAHUN 2014}

investasi. Hal ini berbeda dengan hasil penelitian yang dilakukan oleh Haryanto (2001) yang menyatakan bahwa positive frame mendorong perilaku untuk menghindari risiko. Dalam konteks keputusan investasi, informasi yang disajikan positive frame individu diperkirakan menunjukkan pengurangan preferensi terhadap risiko.

Hasil penelitian oleh Barkah Susanto (2008) menunjukkan bahwa pembingkaian informasi berpengaruh terhadap sifat keputusan yang diambil. Hasil yang berbeda juga terdapat pada penelitian oleh Frasto Biyanto (2001) yang menyatakan bahwa pembingkaian informasi memang berpengaruh terhadap sifat keputusan yang diambil, dan pengaruh tersebut akan semakin berkurang seiring dengan bertambahnya pengalaman individual, sedangkan aspek tanggungjawab tidak memberikan perbedaan pada sifat keputusan yang diambil oleh subjek. Menurut hasil penelitian Amril Arifin (2004) juga menyatakan pada pengujian tambahan, hasil yang diperoleh, yaitu ketika informasi keputusan dapat disederhanakan atau ketika informasi disajikan dalam gaindomain/positive-frame dan lossdomain/positive-frame pengaruh framing akan sangat signifikan terhadap pengambilan keputusan partisipan. Pengambil keputusan yang berada pada kondisi positive frame memutuskan untuk melakukan investasi meskipun hasil penelitian Barkah Susanto (2008), Amril Arifin (2004), Frasto Biyanto (2001), dan Haryanto (2001) menyatakan sebaliknya, hal ini karena pengalaman yang dimiliki oleh partisipan atau pengambil keputusan dalam penelitian ini masih kurang sehingga dalam proses pengambilan keputusan investasi pengambil keputusan tidak terpengaruh oleh kemungkinan kerugian atau risiko yang akan diterima akibat dari keputusan.

Pada pengujian hipotesis kedua diperoleh nilai signifikansi sebesar 0,650 (> $0,05)$ yang berarti hipotesis kedua ditolak. Hal ini menyatakan bahwa hipotesis kedua yaitu manajer pada kondisi negative framing akan lebih cenderung melakukan investasi daripada manajer pada kondisi tanpa framing tidak terbukti.

Hasil penelitian ini berbeda dengan hasil penelitian yang dilakukan oleh Haryanto (2001) yang menyatakan bahwa negative frame dapat mendorong perilaku cenderung untuk mengambil risiko. Dalam konteks keputusan investasi, informasi yang disajikan secara negative frame akan mempengaruhi peningkatan preferensi risiko oleh individu (preferensi atas tambahan investasi).

Tetapi, hasil penelitian ini tidak jauh berbeda dengan hasil penelitian Sany Dwita (2007) yang menunjukkan bahwa kondisi pembingkaian negatif tidak memiliki 


\section{JURNAL NOMINAL / VOLUME III NOMOR 1 / TAHUN 2014}

pengaruh yang signifikan secara statistik terhadap keputusan evaluasi proyek. Hal ini berarti bahwa pada penelitian ini dan penelitian Sany Dwita dapat dinyatakan pembingkaian negatif tidak memiliki pengaruh pada pengambilan keputusan. Selain itu, hasil penelitian Amril Arifin (2004) juga menyatakan ketika informasi keputusan tidak dapat disederhanakan atau ketika informasi keputusan disajikan dalam gain-domain/negative-frame dan lossdomain/positive-frame, pengaruh framing tidak signifikan berpengaruh terhadap pengambilan keputusan partisipan. Tingkat preferensi terhadap risiko yang dimiliki pengambil keputusan pada positive frame maupun negative frame memiliki tingkat yang sama sehingga kecenderungan keputusan pengambil keputusan tidak berbeda.

Pada hasil pengujian dapat diketahui bahwa nilai signifikan yang diperoleh sebesar 0,787. Nilai signifikansi tersebut > 0,05 yang berarti bahwa hipotesis 3 dan 4 tidak terdukung karena variabel Locus of Control tidak memberikan pengaruh atau tidak memoderasi variabel Framing Effect.

Hasil penelitian ini didukung oleh hasil penelitian Andi Irfan (2010) yang menunjukkan bahwa faktor locus of control yang dimiliki oleh seorang manajer dalam menentukan fair atau tidaknya suatu tindakan yang dilakukan oleh perusahaan tidak mempengaruhi tingkat eskalasi komitmen terhadap perusahaan tersebut.

Pada hasil pengujian dapat diketahui bahwa nilai signifikan yang diperoleh sebesar 0,787. Nilai signifikansi tersebut > 0,05 yang berarti bahwa hipotesis 3 dan 4 tidak terdukung karena variabel Locus of Control tidak memberikan pengaruh atau tidak memoderasi variabel Framing Effect.

Hasil pengujian ini berbeda dengan hasil penelitian Endah Suwarni (2011) menunjukkan bahwa individu dengan internal locus of control lebih besar kemungkinan untuk menambah atau melakukan investasi daripada individu dengan external locus of control pada kondisi negative framing.

\section{SIMPULAN DAN SARAN}

\section{Simpulan}

Berdasarkan hasil pengujian yang telah dilakukan maka dapat disimpulkan beberapa hal yaitu, manajer yang berada pada kondisi Positive Framing tidak akan melakukan investasi daripada manajer dengan kondisi tanpa framing. Sementara, manajer pada kondisi negative framing akan melakukan investasi dibandingkan dengan manajer dengan kondisi tanpa framing. Selain itu, Tidak terjadi interaksi antara Locus of Control terhadap Pengambilan Keputusan Investasi sehingga tidak terdapat bukti yang menyatakan bahwa Manajer pada kondisi positive framing dengan internal locus of 


\section{JURNAL NOMINAL / VOLUME III NOMOR 1 / TAHUN 2014}

control akan melakukan investasi daripada manajer pada kondisi positive framing dengan external locus of control serta, Manajer pada kondisi positive framing dengan internal locus of control akan melakukan investasi daripada manajer pada kondisi positive framing dengan external locus of control tidak terbukti.

\section{Saran}

Saran yang dapat diberikan untuk penelitian selanjutnya adalah sebagai berikut:

a. Pada saat pelaksanaan eksperimen, peneliti harus lebih baik dalam menyiapkan kondisi tempat dimana eksperimen akan dilaksanakan karena hal ini dapat mempengaruhi kualitas data yang akan diperoleh. Oleh karena itu, pada penelitian selanjutnya peneliti harus mempertimbangkan dengan baik kondisi dan tempat dimana eksperimen akan berlangsung serta sebisa mungkin meyakinkan partisipan bahwa penelitian ini benar-benar membutuhkan kemandirian dalam pengisian dan ketenangan. Jika ada partisipan yang bertanya atau berkomunikasi dengan partisipan lain, peneliti harus menegur.

b. Pada penelitian selanjutnya sebaiknya partisipan yang digunakan adalah manajer keuangan guna memperoleh hasil penelitian yang lebih akurat. Hal ini karena tingkat preferensi manajer sungguhan terhadap risiko tidak sama persis dengan mahasiswa. Selain itu, tingkat pengalaman juga menjadi faktor utama yang membedakan kualitas keputusan yang diambil oleh mahasiswa dan manajer keuangan. Oleh karena itu, dalam penelitian selanjutnya sebaiknya peneliti bekerjasama dengan manajer keuangan sungguhan dan diteliti pula tingkat preferensi serta pengalaman manajer. Tingkat preferensi dan pengalaman setiap manajer mungkin akan menentukan keputusan seperti apa yang akan dibuat oleh manajer tersebut.

c. Kasus yang digunakan pada eksperimen haruslah benar-benar didesain atau disusun dengan sangat hati-hati sehingga kasus dapat berpengaruh dengan optimal bagi proses pengambilan keputusan partisipan. Hasil penelitian ini menunjukkan bahwa manajer dengan kondisi positive framing maupun negative framing tetap melakukan investasi, hal ini menunjukkan bahwa kasus yang diberikan memang dapat mengarahkan partisipan untuk melakukan investasi. Oleh karena itu, pada penelitian selanjutnya sebaiknya peneliti mendesain kasus yang dapat dengan tegas menunjukkan perbedaan antara kasus pada kondisi positive framing 


\section{JURNAL NOMINAL / VOLUME III NOMOR 1 / TAHUN 2014}

dengan kasus pada kondisi negative framing.

d. Penelitian hanya bekerjasama dengan Mahasiswa Jurusan Pendidikan Akuntansi Universitas Negeri Yogyakarta sehingga hasil penelitian tidak dapat digeneralisasi. Oleh karena itu, peneliti menyarankan agar pada penelitian selanjutnya partisipan adalah manajer keuangan yang tersebar di D.I. Yogyakarta.

\section{DAFTAR PUSTAKA}

Amril Arifin. (2004). Pengaruh Framing Pada Keputusan Akuntansi Managerial Dalam Perspektif Individu-Kelompok; Pengujian Atas Prospect Theory dan Fuzzy-Trace Theory. Tesis, tidak dipublikasikan. Universitas Gadjah Mada.

Andi Irfan. (2009). "Pengaruh Locus of Control Terhadap Hubungan Antara Justice dan Tingkat Eskalasi Komitmen Dalam Penganggaran Modal. Tesis, tidak dipublikasikan. Universitas Gadjah Mada. (2010). Pengaruh Locus Of

Control Terhadap Hubungan Antara Justice Dan Tingkat Eskalasi Komitmen Dalam Penganggaran Modal. Simposium Nasional Akuntansi XIII Purwokerto.04. Hlm.1-26

Andrew Loekman. (2012). Peranan Locus Of Control Dan Justice Terhadap
Eskalasi Komitmen Dalam Pengambilan Keputusan Penganggaran. Berkala Ilmiah Mahasiswa Akuntansi. Vol. 1. No. 2. Hlm 20-24

Arfan Ikhsan \& Muhammad Ishak. (2005).

Akuntansi Keperilakuan. Jakarta : Salemba Empat

Barkah Susanto. (2008). Pengaruh Tanggungjawab, Motivasi Intrinsik Dan Pembingkain Informasi Anggaran Dalam Pengambilan Keputusan Investasi Dengan Group-Shifts Sebagai Variabel Pemoderasi. Tesis tidak dipublkasikan. Universitas Gadjah Mada.

Endah Suwarni, dkk. (2005). Eskalasi dan

De-eskalasi Komitmen Pada Individu Yang Berkarakter Internal Locus of

Control Dalam Kasus Investasi Bertahap. Simposium Nasional Akuntansi XIV Aceh. 042. Hlm.1-40

Frasto Biyanto. (2001). Hubungan

Pembingaian Informasi Anggaran, Tanggungjawab, Dan Pengalaman Terhadap Pilihan Keputusan Pada Investasi Berisiko. Tesis, tidak dipublikasikan. Universitas Gadjah Mada.

Hammond J. S., Keeney R. L., and Raiffa H. (1998). The Hidden Traps in Decision Making. Harvard Business Review. Pp. 1-11

Haryanto. (2001). Pengaruh Framing Dan Jabatan Mengenai Informasi Investasi 
Pada Keputusan Individu-Kelompok

(Suatu Eksperimen Semu). Tesis, tidak dipublikasikan. Universitas Gadjah Mada.

Rahmanto Aji, Sri Hartati, dan Diana Rusmawati. (2009). Hubungan Antara Locus of Control Internal dengan Kematangan Karis pada Siswa Kelas XII SMK N 4 Purworejo. Laporan Penelitian. Universitas Diponegoro.

Robbins, Stephen P.,dkk. (2008). Perilaku Organisasi jilid 2. 12”.ed. Jakarta: Salemba Empat.

Sany Dwita. (2007). Adverse Selection Dan

Pembingkaian Negatif Sebagai

Determinan Dari Eskalasi Komitmen

(Studi Pada Keputusan Evaluasi

Proyek). Tesis, tidak dipublikasikan.

Universitas Gadjah Mada.

Sugiyono. (2001). Metode Penelitian Bisnis.

Bandung: Alfabeta

Usmara A. (2003). Handbook of

Organizations. Yogyakarta: Amara

Books 